\title{
KEPEMIMPINAN KEPALA DESA DALAM PENGELOLAAN PROGRAM 2019 UNTUK PELAYANAN PUBLIK, DI DESA TARO, KECAMATAN TEGALLLANG, KABUPATEN GIANYAR (KAJIAN KOMUNIKASI POLITIK)
}

\author{
I Wayan Sedia \\ Fakultas Ilmu Sosial dan Ilmu Politik Universitas Mahendradatta
}

\begin{abstract}
Abstrak - Walaupun di tengah keterbatasan anggaran, Kepala desa Taro pada tahun 2019 telah mencapai banyak keberhasilan dalam program pelayanannya kepada masyarakat Adapun program tersebut antara lain, program infrasturktur jalan yang dapat mengurangi pengangguran dan kemiskinan, program administrasi kependudukan online, program pembanguanan desa wisata yang memperoleh juara harapan nasional, penghargaan kalpataru dan Program Kelompok Wanita Tani (KWT) meraih juara satu propinsi.

Metode yang digunakan dalam pengumpulan data adalah observasi atau pengamatan oleh peneliti, wawancara peneliti dengan responden, dukumentasi yaitu dengan mengumpulkan tulisan, fhoto tempat penelitian dan kepustakaan, terutama yang ada pada kepustakaan Institut Hindu Dharma Negeri Denpasar. Teknik analisis data dalam penelitian ini menggunakan deskriptif kualitatif yang menekankan makna atas fenomena yang muncul dengan analisis isi (content analisys). Metode deskriptif kualitatif dengan pendekatan analisis isi, untuk memahami komunikasi politik yang dilakukan oleh kepala desa Taro.

Berdasarkan hasil penelitian yang dilakukan, kepala desa Taro dalam kepemimpinannya menggunakan strategi komunikasi politik melalui pelaksanaan visi misi pemerintah desa Taro dengan program kerja. Kerjasama yang telah dilakukan dengan lembaga dinas, adat, kelompok masyarakat, dan media massa serta penggunaan simbul. Fungsi komunikasi politik dilaksanakan dengan memberi informasi membentuk jaringan dan memmberi solusi. Implikasi komunikasi politik kepala desa, dapat meningkatkan kesejahteraan masyarakat dan kemajuan desa Taro.
\end{abstract}

Kata Kunci: Kepemimpinan, Pelayanan Publik, Komunikasi politik

Abstract - In the midst of budget constraints, the village head of Taro in 2019 has achieved a lot of success in his services to the community in the village of Taro. Such as, through the road infrastructure program can reduce unemployment and poverty, online population administration programs, rural tourism development programs that obtain champions of national hope, awards Kalpataru and the Women's Farmers Group Program (KWT) won first place in the province.

The method used in data collection is observation or observation by researchers, researcher interviews with respondents, documentation that is by collecting writings, photos of research sites and literature, especially those in the literature of the Hindu Dharma Negeri Denpasar State Institute. Data analysis techniques in this study used descriptive qualitative which 
emphasizes the meaning of the phenomena that arise with content analysis. This analysis emphasizes the importance of messages in verbal and nonverbal communication. A qualitative descriptive method with a content analysis approach, to understand political communication carried out by the village head of Taro.

Based on the results of research conducted, the Taro village head in his leadership used a political communication strategy through the implementation of the vision and mission of the Taro village government with a work program. Collaboration that has been carried out with government agencies, customs, community groups, and mass media and the use of symbols. The function of political communication is carried out by providing information forming networks and providing solutions. The implications of the political communication of the village head can improve the welfare of the community and the progress of the Taro village.

Keywords: Leadership, Public Service, Political communication

\section{PENDAHULUAN}

Besarnya kewenangan yang diberikan kepada negara kepada keberadaan kepala desa Taro dalam pembangunan, merupakan peluang penting dalam pemberdayaan masyarakat desa khususnya dalam meningkatkan kesejahteraan masyarakat desa Taro. Namun demikian berdasarkan pengamatanpenulis, dalam pelaksanaan programnya disamping beberapa keberhasilan, ditemukan adanya ketimpangan dan hambatan yang terjadi dalam pelaksanaan pelayanan seperti: 1). Proses permohonan dana bantuan masyarakat masih membutuhkan waktu yang cukup lama. Hal ini disebabkan prosedur persetujuan harus melalui beberapa tahapan verifikasi dengan waktu yang tidak pasti.2). Penyelenggaraan rapat terlalu sering sehinggamenyitawaktu pemuka adat dan masyarakat dalam kegiatan adat dan masyarakat sehari-hari. 3). Adanya tuntutan masyarakat yang harus ditangani segera, seperti penanganan bencana longsor.
Komunikasi dua arah yang dilakukan oleh pemerintahan desa Taro dengan kelompok masyarakat sangat baik. Hal ini terbukti dengan respon masyarakat terhadap program desa sebagian besar telah berjalan lancar dan dinikmati anggota masyarakat. Berdasarkan latar belakang di atas, terdapat rumusan masalah yang menjadi pertanyaan kunci, sebagai berikut:

1. Bagaimana Strategi Komunikasi Politik Kepala Desa Dalam Mengelola Program 2019 Untuk Pelayanan Publik, di Desa Taro, Kecamatan Tegallalang, Kabupaten Gianyar ?. Untuk penelitian ini peneliti menggunakan teori komunikasi persuasif yaitu cara mempengaruhi orang lain, sehingga mereka mau secara sadar melakukan sesuai tujuan pemimpin.

2. Bagaimana Fungsi Komunikasi Politik Kepala Desa Dalam Mengelola Program 2019 Untuk Pelayanan Publik, di Desa Taro, Kecamatan Tegallalang, Kabupaten Gianyar?. Untuk membedah permasalahan ini peneliti menggunakan teori teori 
interaksi sosial, yang menekankan pentingnya seorang pemimpin melakukan komunikasi kepada masyarakat.

3. Apa Implikasi Komunikasi Politik Kepala Desa Dalam Mengelola Program 2019 Untuk Pelayanan Publik, di Desa Taro, Kecamatan Tegallalang, Kabupaten Gianyar? . Permasalahan masalah ini menggunakan teori primal leadership yaitu teori mengenai penerapan kepemimpinan sesuai dengan situasi.

Adapun tujuan dari penelitian ini adalah untuk memberikan pemahaman kepada masyarakat mengenai komunikasi politik dan kepemimpinan kepala desa Taro dalam pelayanan publik. Selain itu penelitian ini secara khusus bertujuan meneliti dan menganalisis permasalahan yang telah peneliti uraikan diatas.

Penjelasan Model Penelitian

\section{Model Penelitian}

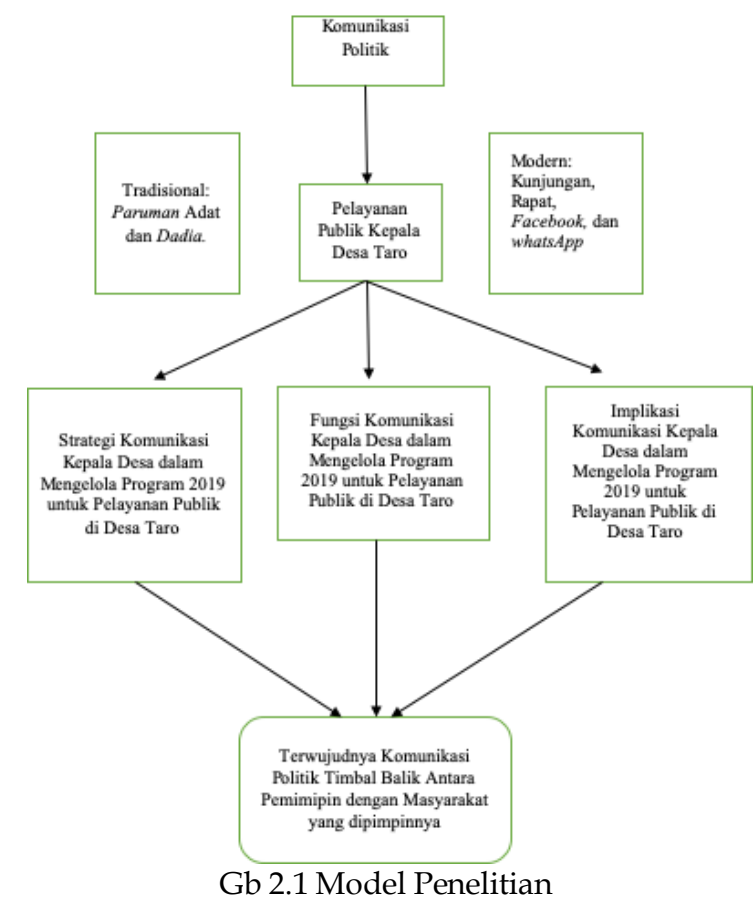

Keterangan Model:

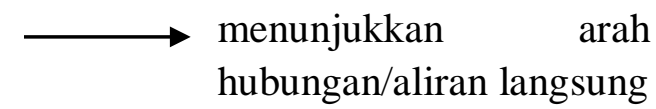

Kepala desa sebagai pejabat publik, komunikasi merupakan hal sangat diperlukan dalam merencanakan, melaksanakan dan dalam melakukan pengawasan termasuk pembagian tugastugas kepada bawahan dan memberikan informasi kebijakan kepada masyarakat. Komunikasi yang dilakukan kepala desa Taro berlandaskan kepemimpinan Hindu yang dipengaruhi oleh komunikasi tradisionil yaitu komunikasi langsung dengan bahasa Bali lokal, melibatkan diri pada rapat atau paruman adat, dadia, dan sekaa taruna taruni, dan komunikasi modern, yaitu melalui kunjungan kerja, surat resmi dan penggunaan media elektronik seperti facebook dan whatsApp. Adapun metode yang peneliti gunakan dalam penelitian ini adalah melalui pengamatan langsung, wawancara, dukumentasi dan kepustakaan yang ada di IHDN, pemerintah kabupaten Gianyar dan desa Taro.

\section{Hasil Penelitian dan Pembahasan.}

3.1 Strategi Kepemimpinan Kepala Desa dalam Pengelolaan Program 2019 untukPelayanan Publik, di Desa Taro, Kecamatan Tegallalang, Kabupaten Gianyar.

Menurut Middleton dalam Cangara (2013:61) strategi komunikasi adalah kombinasi terbaik dari semua elemen komunikasi, mulai dari komunikator, pesan, saluran, penerima, pengaruh yang dirancang untuk mencapai tujuan komunikasi yang optimal.Nimmo (2011: 119) persuasif merupakan : 
Mengubah sikap dan prilaku orang lain dengan menggunakan kata-kata lisan dan tertulis, menanamkan opini baru, dan usaha yang disadari untuk mengubah sikap, kepercayaan, atau prilaku orang melalui transmisi pesan.

\subsubsection{Strategi Komunikasi Verbal Kepala Desa Taro}

Komunikasi verbal merupakan salah satu pilihan dalam berkomunikasi sesuai dengan situasi dan kondisi yang dihadapi. Pada pilihan komunikasi ini pemilihan kata dan nada sangat menentukan keberhasilan komunikator dalam menyampaikan pesannya kepada komunikan.

\section{Komunikasi \\ lisan communication)}

(oral

Berbicara yang sopan dan simpatik dapat menumbuhkan suasana nyaman dan pikiran positif. Suasana demikian dapat memudahkan dalam melaksanakan tugas dan menyelesaikanpermasalahan. Sarasamuccaya 75 juga dimuat sebagai berikut;

Nyang tanpa prawrttyaning wak, pat kwehnya, pratyekanya, ujar ahala, ujar aprgas, ujar picuna, ujar mithya, nahan tang pat singgahananing wak, tan ujarakena, tan angena-ngenan, kojaranya.

Artinya :

Inilah yang tidak patut timbul dari kata-kata, empat banyaknya, yaitu perkataan jahat, perkataan kasar menghardik, perkataan memfitnah, perkataan bohong (tak dapat dipercaya); itulah empat harus disingkirkan dari perkataan, jangan dipikir-pikir akan diucapkan. (Sarasamuccaya, 75)
Ajaran Hindu dapat dipahami dan terapkan dengan baik dalam kehidupan sehari-hari dan dalam kehidupan dalam organisasi sehingga memudahkan dalam pencapaian tujuan organisasi. Kepala desa saat mengakhiri pidato di depan masyarakat. Pantun yang dimaksud juga disampaikan oleh pejabat atau tokoh masyarakat lainnya ketika berpidato. Namun yang menjadi ciri dari kepala desa Taro adalah mengucapkan dua pantun dengan sampiran yang berbeda tetapi memiliki arti yang sama.

"Gunung Agung, Gunung Batur, Gunung Lempuyang

Kirang langkung atur, titiyang nunas ampurayang.

Jukut Kangkung jukut kare

Kirang langkung nunas ampure" (Wawancara, 14/7/2020)

Dari pernyataandiatas, jelaslah komunikasi persuasif membutuhkan kerendahan hari, kepekaan terhadap lawan bicara, memahami adat istiadat setempat dan dalam penyampaiannya diperlukan pemilihan kata-kata dengan bahasa yang sopan dan nada yang jelas. Pantun tersebut juga dapat ditafsirkan bahwa setiap manusia tanpa memandang status ekonomi dan jabatan pasti memiliki kekurangan.

\section{Komunikasi tertulis communication)}

Komunikasi persuasif kepala desa sering pula dilakukan dengan cara tertulis baik melalui visi-misi, program kerja, surat menyurat, dan pamplet. Kelian dusun Sengkaduan menyampaikan bahwa setiap perubahan anggaran selalu diundang rapat. 
Berikut kutipan wawancara peneliti dengan kelihan adat banjar Tatag;

"Setiap penyusunan dan pelaksanaan program desa, utamanya yang terkait dengan adat selalu diinfokan kepada kami secara tertulis, selaku pengurus adat. Untuk sosialisasi program kami juga memasang baliho dan spanduk yang diberikan pihak desa. Ada subprogram linkungan yaitu sanitasi dan sub-prograam kesehatan yaitu; pola hidup bersih dan sehat" (Wawancara denganI Nyoman Karang, 29/6/2020).

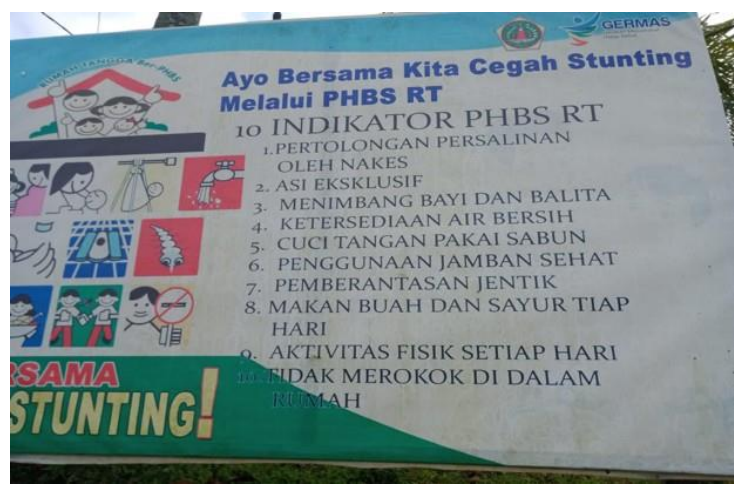

Berdasarkan percakapan dan baliho diatas, mencerminkan komunikasi tertulis dengan berbagai cara untuk menginformasikan program desa telah banyak dilakukan kepala desa. Namun sesuai pengamatan peneliti, di desa Taro masih ada yang belum melek hurup sehingga keberadaan baliho dianggap mubasir.

\subsubsection{Strategi Komunikasi Nonverbal Kepala Desa Taro}

Hal menarik mengenai komunikasi simbolik yang dilakukan oleh kepala desa Taro untuk mengajak masyarakatnya menghargai kebersihan lingkungannya adalah dibentuknya kelompok kebersihan desa yang bernama SampatTaro.Sampat yang digenggam dimaksudkan untuk mengajak masyarakat Taro bersatu disegala bidang kegiatan terutama pada bidang lingkungan. Berikut wawancara peneliti dengan I Wayan Wardika;

"Sampat Taro tyang maksudkan sebagai motivasi dan mendidik masyarakat Taro untuk berkarya, menjaga keasrian lingkungan dan pastilah untuk mencapainya perlu kerjasama seperti sapu itu. Itu makna menurut tyang"(Wawancara peneliti dengan I Wayan Wardika, melalui telepun, 24/7/2020).

Melalui kelompok ini, kepala desa menggerakkan dan mendorong kebersamaan masyarakat dalam mensukseskan program kerja desa.Komunikasi dengan simbul ini tidak saja murah tetapi juga efektif. Terbukti semenjak komunikasi simbolik ini diterapkan masyarakat, kebersihan lingkungan desa semakin meningkat.

Berdasarkan pengamatan dan wawancara diatas dengan responden, strategi nonverbal, seperti senyuman, terlibat aktif pada setiap kegiatan yang menghadirkan masyarakat dan simbulsimbul lainnya, sering lebih ampuh dalam mempengaruhi masyarakat desa Tarountuk mendukung program kerja. Hal ini karena masyarakat desa Taro lebih menghargai perbuatan nyata karena lebih mudah dimengerti.

\subsubsection{Pemanfaatan Media Komunikasi dalam Pelayanan}

Pemerintahan desa melakukan kerjasama dengan Bali Post dan pembuatan instalasi rumah informasi dengan jaringan internet gratis kepada masyarakat. Setiap kegiatan desa dapat diketahui oleh masyarakat, sehingga masyarakat bisa 
mengetahui tujuan dan manfaat kegiatan sekaligus memberi masukan. Rumah informasi dapat digunakan untuk mempromosikan produk warga desa termasukindustri pariwisata. Hal senada juga disampaihkan kepala dusun Patas, I Wayan Balok;

"Kalau dengan Bali Post kerjasama sudah lama dan tersedianya layanan internet gratis yang terhubung dengan kegiatan pemerintahan desa memudahkan masyarakat memperoleh informasi tentang program desa dan sangat membantu titiyang dalam mempromosikan pondok wisata yang baru saja selesai, demikian juga masyarakat lain dalam memasarkan hasil peternakan, pertanian dan produk kerajinan" (Wawancara, 16/5/2020).

Selain media sosial, kerjasama dengan media cetak diantaranya Bali Post juga sudah lama dilaksanakan oleh pemerintahan desa. Sehingga kegiatan dan perkembangan Desa, camat dan kabupaten dengan mudah diketahui.

\subsection{Fungsi Kepemimpinan Kepala Desa dalam Pengelolaan Program 2019 untuk Pelayanan Publik, di Desa Taro, Kecamatan Tegallalang, Kabupaten Gianyar.}

Komunikasi mempunyai beberapa fungsi yaitu fungsi hubungan sosial, fungsi pendidikan, fungsi persuasif, fungsi problem solving dan fungsi terapi. Bungin (2014:274,275,276)

menyatakan, komunikasi organisasi memiliki empat fungsi yaitu; fungsi informasi, fungsi regulatif, fungsi persuasif dan fungsi integratif.

\subsection{Komunikasi Politik Kepala Desa dalam Fungsi Informasi}

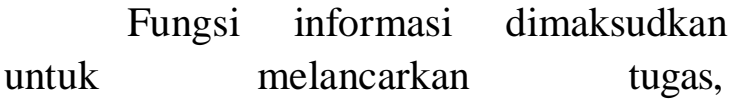
menginformasikan kebijakan desa dan permasalahan yang dihadapi di desa Taro. Senada dengan hal tersebut, berikut wawancara peneliti denganresponden Dewa Adi, kepala dinas pemberdayaan masyarakat desa, mengenai hambatan yang masih ada di desa Taro, dan sampai tahun 2019 masih terjadi.

"Kami sering berkunjung ke Taro dan berkomunikasi dengan aparat, tokoh dan masyarakat luas di sana. Untuk mencari dan mendengar berbagai informasi yang ada." (Wawancara dengan Kadis Pemberdayaan Masyarakat Desa Kabupaten Gianyar, 16/6/2020).

Hal senada juga disampaikan oleh staf camat Tegallalang, I Wayan Sudana, pada wawancara ketika peneliti menanyakan intensitas komunikasi yang dilakukan dan permasalahan yang ada di desa Taro;

"Inggih, ketika ada hubungan kerja dengan programdesa dengan kecamatan koordinasi memang wajib dilakukan dan itu sudah dilakukan oleh fihak desa dengan gamblang baik langsung maupun melalui telpun. Kalau ada problem kami cari solusi bersama, tanpa ada penekanan." (Wawancara, 26/6/2020).

Wawancara diatas menunjukkan komunikasi secara rutin antara aparatur desa Taro rutin lakukan dengan instansi vertikal secara harmonis, leluasa tanpa tekanan dan paksaan yang menyebabkan komunikasi tidak utuh. 
3.2. Komunikasi Politik Kepala Desa dalam MemecahkanMasalah

$\begin{array}{rccc}\text { Mengenai fungsi } & \text { kepala desa } \\ \text { sebagai bagian dari solusi dari }\end{array}$ permasalahan sosial, penggerak dan agen perubahan di desa Taro, menurut informan I Made Sunarka dari banjar Tatag seorang pegawai LPD, kepemimpinan kepala desa memberi pengaruh besar pada perbaikan kondisi masyarakat dan merasa terbantu selama kepemimpinannya.

"Arahan untuk kerja keras dan motivasi yang diberikan kepala desa kaitannya dengan realisasi proyekproyek tahun 2019 sangat sering dan pelaksanaan proyek cukup banyak disini, seperti pembuatan got, jalan alternatif atau jalan lingkar banjar, jalan setapak, bedah rumah, program sanitasi, menggalakkan desa wisata." (Wawancara, 9/5/2020).

Pernyataan yang berbeda diberikan oleh I Wayan Subadia seorang karyawan pada bagian keamanan PT. Gajah Perdana, perusahaan yang bergerak dibidang pariwisata. Berikut pengakuannya dengan peneliti mengenai peran kepala desa dalam penyelesaian masalah ketenagakerjaan.

"Tempat kami bekerja seperti ditempat lain sering ada permasalahan dalam hubungan kerja sesuai dengan hubungan kerja industrial pancasila sesuai UndangUndang Ketenagakerjaan Nomor 13 Tahun 2003. Perselisihan yang sering terjadi yaitu pada aspek keadilan dan kenyamanan kerja seperti, mengenai upah, jam kerja dan permohonan libur saat upacara adat." (Wawancara, 5/7/2020).

Sesuai hasil wawancara tersebut, ruang dan waktu komunikasi yang dilakukan oleh kepala desa sangat leluasa namun seringkali tidak dimanfaatkan secara baik oleh anggota masyarakat. Penyediaan ruang komunikasi politik menurut Bungin (2018:175) "memungkinkan elit politik menyediakan ruang publik untuk berkomunikasi saling menjajaki peluang-peluang yang memungkinkan mereka bertemu dan membincangkan masalah-masalah penting yang sedang dihadapi serta memungkinkan mereka sepakat melakukan hal-hal yang strategis di waktu ini atau waktu yang akan datang”.

\subsection{Implikasi Kepemimpinan Kepala Desa dalam Pengelolaan Program 2019 untuk Pelayanan Publik, di Desa Taro, Kecamatan Tegallalang, Kabupaten Gianyar.}

Nimmo (2010:199,207) setiap diskusi tentang komunikasi politik dan opini politik adalah tingkat dan kondisi keterkaitan yang erat di antara opini publik dan kebijakan pemerintah, yaitu di antara apa yang dipikirkan oleh rakyat dan apa yang dilakukan oleh pemerintah.Bagaimana kesungguhan pembuat kebijakan memperhitungkan opini rakyat.Menurut Silalahi (2005:43), implikasi adalah akibat yang ditimbulkan dari adanya penerapan suatu program atau kebijakan.

\subsubsection{Perubahan Sikap Masyarakat dan Kepatuhan Bawahan}

Sesuai wawancara yang peneliti dengan bagian pemberdayaan masyarakat I Wayan Ardika, hampir setiap program dapat kami terlaksana pada setiap banjar, berkat bantuan tokoh masyarakat dan keaktifan masyarakat, terlepas beberapa 
kekuarangan karena terbatasnya sarana prasarana.

"Kalau mengacu pada data serapan anggaran 2019, mencapai 99 persen dan pencapaian dari programprogram yang direncanakan oleh pemerintah desa Taro 98 persen. Hal ini menandakan kepatuhan tim dan masyarakat dalam mensukseskan program yang kami buat." (Wawancara, 1/5/2020).

Pengalokasian anggaran ini berdampak positif terhadap pengurangan kemiskinan, merangsang minat masyarakat untuk bergerak dalam bidang usaha seperti pembuatan pondok wisata, kuliner dan secara langsung dan tidak langsung mendorong gerakan masyarakat dalam pelestarian lingkungan. Hal serupa juga disampaikan oleh kepala dinas sosial kabupaten Gianyar ketika peneliti melakukan wawancara jarak jauh. Berikut kutipan wawancara on line peneliti dengan bapak Dewa Adi;

"Beberapa keberhasilan dari desa Taro sangat nampak; Pertama, berhasil menurunkan angka kemiskinan dari tahun ketahun. Kedua, Tahun 2019, desa Taro berhasil mengembangkan Desa Wisata dan mendapat juara 1 dalam lomba Desa Wisata Nusantara. Ketiga, Desa Taro berhasil membangun desa dengan konsep pembangunan berwawasan lingkungan sehingga awal tahun 2019 berhasil meraih Trofi Kalpataru dari presiden. Keempat,Desa Taro berhasil melaksanakan pengolahan sampah warga setempat, yang dikelola oleh Bumdes." (Wawancara dengan Kadis Sosial, 16/6/2020).
Berkaitan dengan ini agama Hindu juga mengajarkan untuk senatiasa patuh dengan perintah pimpinan. Regveda VIII.26.16 menyatakan; "tasya vratani-anu vas caramasi". Artinya "kami mematuhi perintah-perintah dari pimpinan" (Titib 1996:487).

\subsubsection{Dukungan terhadap Kebijakan Kepala Desa dalam Pelaksanaan Program}

KelianSubak,banjar Alas Pujung, I Made Karsa, menyatakan program pemerintah desa Taro ini cukup baik terutama dalam mengurus administrasi kependudukan dan pembuatan jalan setapak yang memudahkan masyarakat melakukan kegiatan pertanian, untuk program ini partisipasi masyarakat sangat tinggi. Hal yang senada juga disampaikan oleh I Made Jodog, warga banjar Taro Kelod, yang seringkali mengikuti kegiatan gotong-royong.

"Program pemerintah desa Taro cukup baik, seperti pelayanan dengan sistem sidilan (Sistem Digital dan Pelayanan). Melalui sidilan masyarakat desa Taro dapat melakukan permohonan pelayanan administrasi kependudukan melalui internet." (Wawancara, 5/5/2020).

Masih adanya kendala, seperti banyaknya anggota masyarakat yang belum memahami sistem pelayanan melalui online. Selain itu juga sebagian masyarakat belum memiliki handphone android sehingga mereka tidak masuk dalam sistem jaringan. Sampai saat ini imput data seperti, data kartu tanda penduduk masih dilakukan staf desa. 